\title{
The efficacy of cefuroxime for the treatment of acute gonorrhoea in men
}

\author{
J. D. PRICE AND J. L. FLUKER \\ From the West London Hospital, Charing Cross Hospital Group, London
}

SUMmARY This is a report on a clinical trial in which cefuroxime was used for treating 110 men with uncomplicated urethral gonorrhoea. Twenty-three men were given $1 \mathrm{~g}$ cefuroxime intramuscularly and $1 \mathrm{~g}$ probenecid orally, and 87 were treated with $1.5 \mathrm{~g}$ cefuroxime intramuscularly with $1 \mathrm{~g}$ probenecid orally. All 18 patients treated with $1 \mathrm{~g}$ cefuroxime and $1 \mathrm{~g}$ probenecid and seen at least once after treatment, were cured. Sixty-six (98.5\%) of 67 patients treated with $1.5 \mathrm{~g}$ cefuroxime and $1 \mathrm{~g}$ probenecid and seen at least once after treatment, were cured. No side effects were reported. The high cure rates compared favourably with other antibiotics now in regular use and cefuroxime should be of great value especially for patients infected with $\beta$-lactamase producing gonococci.

\section{Introduction}

Since its introduction, penicillin has been the drug of choice for treating gonorrhoea as, until recently, most strains have been susceptible to low serum concentrations of penicillin. Since 1958 less sensitive strains of gonococci have been cultured and greater doses of penicillin have been necessary (Curtis and Wilkinson, 1958).

The Medical Research Council (1961) showed that $13.2 \%$ of gonococci had a minimum inhibitory concentration (MIC) of between 0.125 and $1.0 \mathrm{u} / \mathrm{ml}$. Gray et al. (1970) at St Thomas's Hospital found that $35 \%$ of strains showed partial resistance $(\mathrm{MIC} \geqslant$ $0.06 \mu \mathrm{g} / \mathrm{ml}$ ). At the Charing Cross Hospital, Beck (1973, personal communication) reported that $9 \%$ of penicillin-sensitive gonococci had an MIC of between 0.25 and $1.0 \mathrm{u} / \mathrm{ml}(0.15$ to $0.6 \mu \mathrm{g} / \mathrm{ml})$ and $4 \%$ had an MIC above $1.0 \mathrm{u} / \mathrm{ml}$.

Gray et al. (1970), using 5 megaunits of benzylpenicillin in $8 \mathrm{ml}$ lignocaine with $1 \mathrm{~g}$ probenecid orally in 200 patients treated in London, had one failure $(0.5 \%)$ in the 185 who returned for followup. Olsen and Lomholt (1969) had a relapse rate of $1.0 \%$ in 832 cases similarly treated in Greenland. The Center for Disease Control (1974) in Atlanta, USA, recommended a single dose of either 4.8 megaunits of penicillin or $3.5 \mathrm{~g}$ ampicillin with $1 \mathrm{~g}$ probenecid for treating uncomplicated urethral gonorrhoea. Kvale et al. (1971) using $3.5 \mathrm{~g}$ ampicillin plus $1 \mathrm{~g}$ probenecid had a $4 \%$ failure rate in

Address for reprints: Dr J. D. Price, Glaxo Holdings Limited, Medical Department, Graham Street, London N1 8JZ

Received for publication 4 July 1977 the Philippines. Price et al. (1977) giving $1.4 \mathrm{~g}$ talampicillin had a $1.6 \%$ failure rate in London.

With the appearance of $\beta$-lactamase producing strains of gonococci, the effectiveness of the $\beta$-lactam antibiotics is being questioned (Ashford et al., 1976). Cefuroxime, a new $\beta$-lactamase stable cephalosporin, has been developed which, from in vitro sensitivity tests in Liverpool (Percival et al., 1976) and at St Thomas's Hospital, London (Phillips et al., 1976), is effective against $\beta$-lactamase producing gonococci.

Cefuroxime is a semisynthetic analogue of cephalosporin $\mathrm{C}$ and, as shown in the formula, has a methoxyimino group and a furyl group on the side-chain attached to the nucleus at position 7 (Figure). This stabilises the $\beta$-lactam ring against the bacterial $\beta$-lactamases. Cefuroxime has a broad spectrum of activity and is resistant to $\beta$-lactamases produced by Gram-negative organisms ( $O^{\prime}$ Callaghan et al., 1976). Cefuroxime is excreted unchanged in the urine.

Cefuroxime is not absorbed orally and has to be given intramuscularly or intravenously. The serum concentrations are dose related and a peak concentration of $40 \mu \mathrm{g} / \mathrm{ml}$ is reached half to one hour after

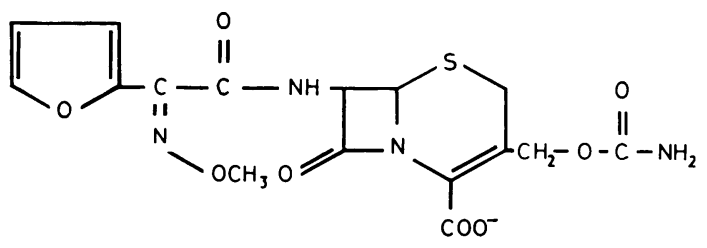

Cefuroxime

Figure Cefuroxime structural formula 
giving $1 \mathrm{~g}$ intramuscularly. Levels can still be estimated after eight hours (Foord, 1976) and 33\% is bound to serum protein.

We have assessed the efficacy and tolerance of two different single dose levels of cefuroxime with oral probenecid for the treatment of acute uncomplicated urethral gonorrhoea in men.

\section{Method}

Men suffering from urethral gonorrhoea provisionally diagnosed by the appearance of typical diplococci in a Gram-stained smear were included in the study, provided that they were not known to be allergic to cephalosporins or to have had a previous anaphylactic reaction to penicillin. Cultures on modified Martin Thayer medium (Riddell and Buck, 1970) were incubated for bacteriological identification and MIC determination. The patients were then given cefuroxime by intramuscular injection, the $1 \mathrm{~g}$ dose being dissolved in $4 \mathrm{ml}$ of water for injection, the $1.5 \mathrm{~g}$ dose being given as $750 \mathrm{mg}$ dissolved in $3.0 \mathrm{ml}$ into each buttock. All patients were instructed to refrain from alcohol for the first week after the injection and from sexual intercourse until completion of the review. Patients were asked to return after 4, 7, and 14 days for follow-up assessment, or at any time if the symptoms returned. At each follow-up visit a history was taken and the patient examined. Samples of deposit from centrifuged urine and deep intraurethral exudates were stained and examined in the clinic.

\section{Results}

One hundred and ten men who were attending the clinic with acute uncomplicated gonorrhoea were randomly included in the study after positive identification of Gram-negative diplococci in the urethral smear. The first 23 patients received $1 \mathrm{~g}$ cefuroxime, and the next 87 patients received $1.5 \mathrm{~g}$ cefuroxime. All received $1 \mathrm{~g}$ of probenecid at the same time as their injection.

E.ighty-four patients were between 18 and 30 years or age, $79 \%$ were single, only $16 \%$ were married, and $5 \%$ were either divorced or separated. Sixtyeight per cent of the patients were Caucasian, $29 \%$ Negroid, and $3 \%$ Asian.
Two patients had already received antibiotics. One had received $3 \mathrm{~g}$ ampicillin and $1 \mathrm{~g}$ probenecid orally which had failed to cure his gonorrhoea and the other patient had been given different antibiotics but was repeatedly reinfected by the same contact. Cefuroxime was followed by cure in both these cases.

\section{BACTERIOLOGICAL RESPONSE}

Cultures from 37 of the 110 cases were sent to the Microbiology Department, Glaxo Research for MIC determination. Their sensitivity to penicillin G showed that three organisms had an MIC of between 0.11 and $0.5 \mu \mathrm{g} / \mathrm{ml}$ (Table 1).

Of the 23 patients treated with $1 \mathrm{~g}$ cefuroxime and $1 \mathrm{~g}$ probenecid, 18 returned for at least one follow-up and in all 18 cases Neisseria gonorrhoeae was successfully eradicated.

In the second group of 87 patients given $1.5 \mathrm{~g}$ cefuroxime and $1 \mathrm{~g}$ probenecid, 67 patients returned for follow-up, 60 were successfully treated, two were confirmed reinfections, and in one, treatment failed. Forty patients returned for a second follow-up and 10 patients returned for a third time. The 23 unassessable patients had no microbiological sample taken after the initial visit. In all, treatment was clinically successful.

In these 110 cases treated, 80 patients were assessable. The overall bacteriological response was only one failure- $98.5 \%$ (Table 2 ).

CLINICAL RESPONSE

The clinical response was assessed as follows:

Table 2 Bacteriological response

\begin{tabular}{llll}
\hline & \multicolumn{2}{l}{ No. of patients treated with } & \\
\cline { 2 - 3 } & $\begin{array}{l}1 \mathrm{~g} \text { cefuroxime } \\
\text { and } 1 \mathrm{~g}\end{array}$ & $\begin{array}{l}1.5 \mathrm{~g} \text { cefuroxime } \\
\text { and } 1 \mathrm{~g} \\
\text { probenecid }\end{array}$ & Total \\
Result of treatment & 17 & 60 & 77 \\
Successful & 1 & 1 & 2 \\
$\begin{array}{l}\text { Successful with } \\
\text { reinfection }\end{array}$ & - & 1 & 1 \\
$\begin{array}{l}\text { Failed } \\
\text { Reinfection }\end{array}$ & - & 2 & 2 \\
Unassessable* & 5 & 23 & 28 \\
Total assessable & 18 & 62 & 80 \\
\hline
\end{tabular}

*Neither smear nor culture taken after first visit

Table 1 MIC of isolated organisms

\begin{tabular}{|c|c|c|c|c|c|c|}
\hline \multirow[b]{2}{*}{ Cefuroxime $\mu \mathrm{g} / \mathrm{ml}$} & \multicolumn{5}{|c|}{ Penicillin $G(\mu g / m l)$} & \multirow[b]{2}{*}{ Total } \\
\hline & $0.0004-0.005$ & $0.006-0.01$ & $0.011-0.05$ & $0.06-0.1$ & $0 \cdot 11-0 \cdot 5$ & \\
\hline $0.0004-0.005$ & 11 & 1 & 1 & - & - & 13 \\
\hline $0.006-0.01$ & 7 & 6 & - & - & - & 13 \\
\hline $0.011-0.05$ & - & 3 & 3 & 2 & 1 & 9 \\
\hline $0.06-0.1$ & - & - & - & - & $i$ & 1 \\
\hline $0.11-0.5$ & - & - & - & - & 1 & 1 \\
\hline Total & 18 & 10 & 4 & 2 & 3 & 37 \\
\hline
\end{tabular}


Table 3 Clinical response

\begin{tabular}{|c|c|c|c|}
\hline \multirow[b]{2}{*}{ Result of treatment } & \multicolumn{2}{|c|}{ No. of patients treated with } & \multirow[b]{2}{*}{ Total } \\
\hline & $\begin{array}{l}1 \mathrm{~g} \text { cefuroxime } \\
\text { and } 1 \mathrm{~g} \\
\text { probenecid }\end{array}$ & $\begin{array}{l}1.5 \mathrm{~g} \text { cefiuroxime } \\
\text { and } 1 \mathrm{~g} \\
\text { probenecid }\end{array}$ & \\
\hline Cured & 13 & 58 & 71 \\
\hline $\begin{array}{l}\text { Cured with } \\
\text { reinfection }\end{array}$ & 1 & 一 & 1 \\
\hline Improved (PGU) & $3\left(17 \cdot 6^{\circ}{ }_{0}\right)$ & $\overline{2}\left(3_{0}^{\circ}\right)$ & $\begin{array}{l}1 \\
5\end{array}$ \\
\hline Unassessable & 6 & 27 & 33 \\
\hline Total assessable & 17 & 60 & 77 \\
\hline
\end{tabular}

(1) Cured with complete remission of all signs and symptoms. (2) Cured with subsequent reinfection. (3) Symptoms improved but signs of post-gonococcal urethritis (PGU) present. (4) Unassessable if initially asymptomatic, or if symptoms present within 14 days of treatment and the patient given other treatment or was not followed up.

Eighteen of the patients treated with $1 \mathrm{~g}$ cefuroxime and $1 \mathrm{~g}$ probenecid returned for a first follow-up. If patients did not return for a follow-up 14 days after treatment, clinical assessment was made according to the information from the last visit. This is shown in Table 3.

In the second group of patients (that is, those given $1.5 \mathrm{~g}$ cefuroxime and $1 \mathrm{~g}$ probenecid) 67 patients returned for at least one follow-up. Fiftyeight patients had relief of all signs and symptoms.

Five patients had PGU. In those treated with $1 \mathrm{~g}$ cefuroxime and $1 \mathrm{~g}$ probenecid, PGU occurred in three of 17 patients $(17.6 \%)$. In those treated with $1.5 \mathrm{~g}$ cefuroxime and $1 \mathrm{~g}$ probenecid, PGU occurred in two of 60 patients $(3 \%)$. In Table 3 the clinical response and the incidence of PGU is shown.

\section{SIDE EFFECTS}

No side effects were reported, even in the four patients who had a history of antibiotic allergy. Mild transient pain was noted in all cases on injection.

\section{Discussion}

When drugs other than penicillin are used to treat gonorrhoea, it is essential that comparable success rates be obtained. Patients with a known hypersensitivity to penicillin, or those in whom syphilis may be present, single dose treatment with cotrimoxazole and spectinomycin is used.

Carroll and Nicol (1970) in a trial of 111 cases using co-trimoxazole had a failure rate of five $(4.5 \%)$. Reyn et al. (1973) had one failure in 109 cases. Kanamycin $2 \mathrm{~g}$ by injection as reported by Wilkinson et al. (1967), Hooton and Nicol (1967), and Fluker and Hewitt (1970) gave failure rates of about 3 to $5 \%$. Siboulet and Durel (1961) in Paris using spiramycin $2 \cdot 5 \mathrm{~g}$ had 20 failures $(3 \%)$ out of 594 patients.

Compared with these results, cefuroxime at $1.5 \mathrm{~g}$ has a very good success rate.

We wish to thank the members of the medical and nursing staff in the Luke Clinic, West London Hospital for their help in obtaining and treating the patients, Dr A. Gerkin and Mr D. Platt at the West London Hospital laboratories, Miss M. Marshall and Miss M. Kennedy for their bacteriological help, and Miss M. Rees for her evaluation of the data and Miss $\mathbf{J}$. Bush for secretarial assistance.

We should also like to thank Miss B. Mullinger and Glaxo Research Limited for supplies of cefuroxime.

\section{References}

Ashford, W. A., Golash, R. G., and Hemming, V. G. (1976). Penicillinase-producing Neisseria gonorrhoeae. Lancet, 2, 657-658.

Carroll, B. R. T., and Nicol, C. S. (1970). Trimethoprim/sulphamethoxazole in the treatment of non-gonococcal urethritis and gonorrhoea. British Journal of Venereal Diseases, 46, 31-33.

Center for Disease Control (1974). Publication No. (CDC) 75-8195, p. 14. Department of Health Education and Welfare: Atlanta.

Curtis, F. R., and Wilkinson, A. E. (1958). A comparison of the in vitro sensitivity of gonococci to penicillin with the results of treatment. British Journal of Venereal Diseases, 34, 70-82.

Fluker, J. L., and Hewitt, A. B. (1970). Kanamycin in the treatment of rectal gonorrhoea. British Journal of Venereal Diseases, 46, $454-456$.

Foord, R. D. (1976). Cefuroxime: Human pharmacokinetics. Antimicrobial Agents and Chemotherapy, 9, 741-747.

Gray, R. C. F., Phillips, I., and Nicol, C. S. (1970). Treatment of gonorrhoea with three different antibiotic regimes: Doxycycline $300 \mathrm{mg}$, procaine penicillin plus benzyl penicillin $2.4 \mathrm{~m}$.u., benzyl penicillin $5 \mathrm{~m}$.u. plus probenecid. British Journal of Venereal Diseases, 46, 401-403.

Hooton, W. S., and Nicol, C. S. (1967). Kanamycin in the treatment of gonorrhoea in females. Postgraduate Medical Journal. Supplement, 43, 68-71.

Kvale, P. A., Keys, T. F., Johnson, D. W., and Holmes, K. K. (1971). Single oral dose ampicillin and probenecid treatment of gonorrhoea in the male. Journal of the American Medical Association, 215, 1449-1453.

Medical Research Council (1961). Resistance of gonococci to penicillin. Working Party report. Lancet, 2, 226-230.

O'Callaghan, C. H., Sykes, R. B., Griffiths, A., and Thornton, J. E. (1976). Cefuroxime: a new cephalosporin antibiotic activity in vitro. Antimicrobial Agents and Chemotherapy, 9, 511-519.

Olsen, G. A., and Lomholt, G. (1969). Gonorrhoea treated by a combination of probenecid and sodium penicillin G. British Journal of Venereal Diseases, 45, 144-148.

Percival, A., Rowlands, J., Corkill, J. E., Alergant, C. D., Arya, O. P., Rees, E., and Annels, E. H. (1976). Penicillinase-producing gonococci in Liverpool. Lancet, 2, 1379-1382.

Phillips, I., King, A., Warren, C., and Watts, B. (1976). The activity of penicillin and eight cephalosporins on Neisseria gonorrhoeae. Journal of Antimicrobial Chemotherapy, 2, 31-39.

Price, J. D., Fluker, J. L., and Giles, A. J. H. (1977). Oral talampicillin in the treatment of gonorrhoea. British Journal of Venereal Diseases, 53, 113-114.

Reyn, A., Schmidt, H., Trier, M., and Bentzon, M. W. (1973). Spectinomycin hydrochloride (Trobicin) in the treatment of gonorrhoea. British Journal of Venereal Diseases, 49, 54-59.

Riddell, R. H., and Buck, A. C. (1970). Trimethoprim as an additional selective agent in media for the isolation of Neisseria gonorrhoeae. Journal of Clinical Pathology, 23, 481-483.

Siboulet, A., and Durel, P. (1961). A new 'one-minute' treatment of gonorrhoea. British Journal of Venereal Diseases, 37, 240-243.

Wilkinson, A. E., Race, J. W., and Curtis, F. R. (1967). Kanamycin in the treatment of gonorrhoea in males. Postgraduate Medical Journal, Supplement, 43, 65-67. 